\title{
2 US Improv Comedy and Race - A Sketchy Report
}

\subsection{Arresting improv}

Improvisation is ephemeral, transient, and cannot be captured. What is true for improv as a special kind of stage performance is also true for its academic analysis. Yet, improv or improvisational theater, is gaining momentum in academic consideration. Scholars analyze poetics, write chronological histories of its aesthetic development, delve into fantasies of orality, truthfulness, and humanity, or re-discover allegedly lost didactics. In most studies, theatrical (or other) improvisation serves as a means of discussing something else: concepts of emergence, models for creativity, antidotes for depression, effective team-building, non-authoritarian creativity, artificial intelligence, and humanity as such. The number of TEDx talks that mobilize a core feature of improv practice - the "yes, and" principle - is steadily on the rise. Improvisation is a hot topic, and we practitioners usually claim we've always known that. However, the mere application of various principles of improvisation to different fields does not necessarily tell us more about improv itself, and very few scholars work on improv in its theatrical variant. Gunter Lösel is one of the few who attempts to figure out disciplinary and definable frames for talking about improv - for example, in his differentiation between improv as an autonomous art form or a cultural impulse ("Phänomen Impro"). Both frames can help us see improv, and both offer an interesting take on the practice. Nevertheless, Lösel's underlying assumption that artistic expression and cultural impulses are separate spheres of cultural activity is, in my opinion, dated and grounded in an implicit hierarchy between high and low popular culture. Such approaches thus amount to little more than the accumulation of works that academize improv with little payoff. When scholars approach improv, then, we do not necessarily mean the same thing. We assume that we share ideas or interests - such as creativity, emergence, and collectivity but that is not always the case. We assume we are talking about the same thing in different languages or disciplines, but we forget that changing the frame changes the thing. We must understand that scholarship is always interested, and that its object is constructed by the methodological design, by the selection of material, by the doxastic environment and methodological procedures. The scholar before their object is Goodman's spectator before a painting: just as there is no virgin eye in art reception, there is no objective method. Instead, all we can do is a) describe what we're drawing on to create the object in the first place, and b) reflect on and present our own theoretical and methodological 
axioms. The former is the subject of this chapter, and the latter will be considered in the following one.

This project understands improv as a theatrical stage practice (aestheticized play) based on spontaneous decision-making (intuition) practiced in local and global communities of the modern West, mostly aiming to be comedic (humor). These three planes, though structured in three chapters, shine through the argument at all times and must be understood in their simultaneity and transareality. Where other theorizations of improvisation work with improvisational concepts concerning something else, I develop an analysis of improv's libidinal economy. This project aims to feed into the theory of improv as a stage performance - not the other way around. Further, I focus on the realities of what actually happens rather than the allegedly endless potential of improvisation, and on questions of racism and anti-Blackness as they speak through theatrical improvisation. Improv is neither solely an aesthetic modality nor merely a stage practice. It is also a cultural space, which I differentiate into actual social spaces - people who practice and perform improv - and discursive space, which is generated by and feeds back into the social spaces. This discursive space encompasses everything said about improv from within and without, from blogs to podcasts to printed how-to manuals and various almanacs of improv, as well as the positions that non-improvisers take towards it. I draw no significant line between academic and practical discourses on improv because both fall into selfidealization. This project is not concerned with affirmative or reproductive historiography or celebrations of self-proclaimed political idealism as performed through a theory of absolute aestheticism. Although I am by no means an opponent of theory (as the reader will soon discover), I ground my analysis in realworld performance practices. I write with actual stage performances in mind, or discussions with people who have told me about their stage experiences and not improvisation's presumed "capacity to trouble the assumptions [...] fostered by dominant systems of knowledge production" (Caines and Heble 3). The position that imagines improv as a space for radical oppositionality and social improvement is held by many improvisers. When asked how improv compares to other art forms with regard to discriminatory practices and exclusion, renowned improviser $\mathrm{TJ}$ Jagodowski ${ }^{1}$ says:

1 TJ Jagodowski began improvising in the mid-1990s. He has learned, taught, performed, or directed in all the improvisational theaters of Chicago. He has been at iO Chicago for twenty years, at the Annoyance for fifteen, and wrote and performed in two Second City reviews. His commercial, TV, and film credits include the Sonic ads, Stranger than Fiction, Ice Harvest, The Great and Powerful Oz, Prison Break, and Get Hard. He can also be seen in the 2018 web series Studio B. Together with his partner David Pasquesi, TJ has performed the fully improvised "TJ \& Dave" 
Even though I think improvisation was slow to come to greater diversity, I think it holds great, if not the greatest, ability to deal with it. Improvisation allows the performer the most freedom of any art form to speak their minds directly and without editor. To speak from their direct experience most momentarily. But it is also inhibited in affecting change by its audience size and impermanence. A book or film can reach millions and is a permanent work. It can be studied and peeled apart. It can be disseminated widely. The improv performance is often to a group of $20-100$ and vanishes into thin air. The tenets can be spread wide, but again that's through missionary work by teaching $10-20$ students at a time. (Jagodowski, personal email, 16 Oct. 2019)

While the improviser in me agrees in part with the position that improv has the potential to deal with discrimination in theory, the theorist in me is curious about this assumption's paradoxical relationship with reality. I hope that my approach, located precisely in that paradox, will prove productive and go beyond the mainstream reiterations that make up the bulk of academic improv theorization.

\subsection{Introduction to Chicago improv}

I am working within American Studies and therefore focus on the type of improv developed and institutionalized in the US. Yet, my three planes of analysis (intuition, play, humor) and my axiomatic framework (a theory of modern anti-Blackness focusing on its libidinal dimension with psychoanalytic models) could speak with no loss of significance to the several European traditions of improvisation. Improv has been inserted discursively into various historiographic strands and different trajectories, and European styles have developed without conscious reference to the improv practices in the US. They often reflect artistic approaches distinct from comedic entertainment and do not relate as much to the comedy industry as US improv does. However, much of what I am consider-

show on many stages throughout the USA, Canada, and Europe. The show has won numerous awards, such as the Del Close award two years in a row (2003 and 2004), and the Nightlife Award New York (2006 and 2007). Both performers have been celebrated as the "Chicago Improviser(s) of the Year" (2006) and Chicago Reader named "TJ and Dave" as the "Best improvised Show" in 2008. Among critics, colleagues, and audiences, Jagodowski is widely considered as one of the best improvisers currently performing. See further their duo website and their book, Improvisation at the Speed of Life (with Pam Victor). Our conversation took place in March 2015 in Chicago, together with David Pasquesi. The authorized material used in this project is drawn from a follow-up email exchange in October 2019. 
ing here also applies to these stage practices, and one needs to start somewhere even if the object of study is as boundless as improv.

Geographically, I focus on Chicago, historically the institutional source for US improv culture as it is known today. For many, Chicago has always been the place to go for training in the comedy entertainment industry. Amy Seham calls the city "a mecca for young improvisers who want to study it at its source" (xvii). The Chicago improv scene remains an active sphere where people are trained and socialized to enter comedic entertainment at large. With Second City "as a stepping-stone to Saturday Night Live and other opportunities in film and television" as its preliminary endgame (Seham xvii), we can read Chicago as a hotbed for the development and cultivation of comedic talent, and the space in which this talent gets unpaid stage time and opportunity to present itself:

When I decided I really wanted to pursue comedy, I feel like Chicago is the kind of city where, wherever you come from, whatever small town you were at, you're trying to hit the ceiling there. And if you could make it in Chicago, I feel like it's a good stepping stone to either go east or west or even London or whatever. (Joel Boyd, personal conversation)

Based on the number of students, performance frequency, historical interconnections, and success in terms of popular fame, three Chicago improv institutions stand out: Second City, iO (formerly ImprovOlympic), and The Annoyance Theatre. These three are referenced most often in the interviews, and represent different focal points of central aspects in improv: the communal, the satirical, and the dirty. The schools have distinct aesthetics and provide different frames and styles for training and performance. They generate different audience expectations, identification points, and frames for self-perception. Claims for distinction from other schools are made along similar lines. Such distinctions are most pronounced in published manuals, histories, encyclopedias, and almanacs: the Second City has published the Almanac of Improvisation (Libera 2004), the iO is represented in the seminal Truth in Comedy (Close et al. 1994) and later Art by Committee (Halpern 2006), while Mick Napier describes the Annoyance style in Improvise. Scene from the Inside out (2004) and Behind the Scenes (2015). Each institution advertises its training centers and classes through the names of alumni who have made it, such as Tina Fey, Keegan-Michael Key, Stephen Colbert, Dan Castellaneta, Scott Adsit, Rachel Dratch, Amy Poehler, Tim Meadows, Andy Richter, and many more. Credibility and authority on all things improv and comedy are further marked by the school-specific manuals, historiographies, and their preface-writers: Mike Myers vouches for Truth in Comedy, Adam McKay believes in Art by Committee, and Bob Odenkirk cherishes Mick Napier's 
Behind the Scenes. Second City's Almanac of Improvisation (2004) features texts by Anne Libera, Tim Kazurinsky, Tina Fey, and many others. However, assigning these public figures to individual schools or institutions is arbitrary: Mike Myers is also an alumnus of Second City, Bob Odenkirk performed at the Second City as well, and so on. Actors who have gone on to great fame can be as easily associated with the $\mathrm{iO}$ as with Second City, like John Belushi or Bill Murray.

One institution outside Chicago needs to be mentioned here: The Upright Citizens Brigade Theatre (UCB) in New York City. Founders Matt Besser, Matt Walsh, Ian Roberts, and Amy Poehler were students at the $\mathrm{iO}$ in Chicago before they went to New York and set up the UCB. Its success was enormous, and UCB has become another hallmark of Western, US-based improv. It too has a manual: The Upright Citizens Brigade Comedy Improvisation Manual (2013). Their official training website announces that UCB alumni have gone on to become successful "writers and performers for Saturday Night Live, The Tonight Show with Jimmy Fallon, Broad City, Key \& Peele, Silicon Valley, Veep, Atlanta, Brooklyn NineNine, Crazy Ex-Girlfriend, The Daily Show, Inside Amy Schumer, Master of None, Drunk History, Full Frontal with Samantha Bee” and others. The UCB's training program has earned it a central role in the wider entertainment industry; their website calls it "the only accredited improv and sketch comedy school in the country." Improv training is common amongst comedic performers on TV, and in casting for films, improvisers are often given preferred treatment over actors who graduate from traditional theatre or drama schools. TV and streaming productions increasingly feature improvisers: series like Curb Your Enthusiasm or 30Rock draw primarily on improvisation and cast people specifically trained in it. The cast of Saturday Night Live (SNL), the endgame for comedic performers, regularly features improv-trained members.

While training in improv and active participation in the scene may eventually lead to jobs in the industry, in the early stages it demands time, money, and a willingness to network and socialize. Stage improvisation rarely pays, and hardly anybody can live only on performing improvised shows. What improv offers to its young practitioners is stage time, performance practice, and the training to produce funny material quickly for all kinds of comedy. Participating in improv as such is an expensive endeavor and a social and financial privilege:

Bullock: The amount of jobs that improvisers can get here that pay money is a small percentage in comparison to the amount of improvisers there are. So it still seems like most time when you're auditioning, it's not for anything you know is going to pay. A lot of times, it's just for exposure, to be on a team - and hopefully, a popular team that people will see, and then maybe they will let you work for free for a while, and then maybe they might hire you. 
Perkins: And a lot of times that you audition, you have to pay for it. You have to pay for the coach. There's not a lot of financial gain.

Bullock: It's a lot of investment. I had to spend so much money before I ever started making money doing improv.

Perkins: There are things like internships at certain places. But then you have to invest so much time. That is a lot to give to this art until you are able to be paid for it.

Bullock: And even then there's not enough jobs for everyone who works hard and pays all this money. It's not a thing you do to make money. It's a thing you do to build skills that will help you make money. (personal conversation)

This social and symbolic capital can outweigh the cost of classes. Improv also provides a social space for people to get together, a large community of improvisers who are happy to practice and perform together, who share their worlds on- and off-stage. Social relationships also provide access to stage opportunities:

The community is active. It works so much on getting to know people. That's how you get stage time. These smaller theaters, they don't pay. You get to know people; you make teams; it has to be social. There are a few places in which you can audition and put on a team, but for the most part, teams are independently made just through people you kinda like. (Bullock, personal conversation)

I've been doing theater since I was a kid, fourteen years old. Improv pretty consistently since 2001. My father met Charna, and he was like, "My homegirl got a theater, it's called the iO, and you'll do good there.” That's where I started. I was one of the first interns for the TJ\&Dave show. Charna was nice enough to let me take the classes for free because of my dad. (Johnson, personal conversation) ${ }^{2}$

Chicago improv is an intricate entanglement of social life, practical training, and opportunities to start building a career in the entertainment industry. There is a strong link between social capital - having a lot of friends and the kind of humor

2 Warren Phynix Johnson graduated from improv programs at iO Chicago, ComedySportz Chicago, and Second City. His stage credits include "Pimprov," The Second City's National Touring Company "RedCo," Second City revue "The Second City Does Baltimore," Crossbreed Comedy with Laugh Factory's house team, "Bastards Of The Underground," "Lady Mechanics," and "Awful People Present: Stealing From The King Unabridged” (both at The Annoyance Theater). Johnson has hosted Chicago Public Schools' own television series CPS RIGHT NOW. He has performed in Improv Unlimited (corporate improv shows) and was an ensemble member in McDonald's Corp's only traveling improv show, “America's Next Success Story.” He has featured in several net commercials (Comcast SportsNet and McDonald's), and broadcasts weekly on B.A.D. Waves on Que4Radio (que4.org/itunes Radio) with the Bastards Of The Underground. Our conversation took place in March 2015 in Chicago, together with Dacey Arashiba and Derek Schleelein. The material used in this project was authorized by Johnson via Facebook Messenger on 7 October 2019. 
to which a majority can relate - and career opportunities. Being able to get into improv requires financial investment or personal connections. Without financial capacity and social connections, the joys of improv are inaccessible to many (including potential access to or success in the comedic industry).

Some describe improv's exclusive dynamics, the power of social capital, and the heavy investment in belonging as cultish, usually with a strongly negative connotation. Stand-up comedian Peter-john Byrnes works the cult metaphor in a 2017 article for the Chicago Reader titled "Why improv is neither funny nor entertaining, according to a stand-up comedian:”

Improv is to comedy as Scientology is to religion: it suckers white people into paying ever more expensive fees to the organization to gain higher levels of achievement. Like any cult, its hierarchies are of endless fascination to those within it and deadly boring to those without. And like Scientology, improv is centered around a messianic leader, though the example of the late Del Close suggests that L. Ron Hubbard would have been even more toxic if he'd had a smack habit. ${ }^{3}$

The semi-ironic religious connotations of being part of the iO "cult" are articulated not only by those denouncing it, but are fostered by the theater itself. The iO mainstage is named after the late Del Close, whose role in improv cannot be denied: as a teacher, performer, and mentor, he directly influenced much of Second City's history, and was the artistic mind behind the foundation of the iO and the development of the Harold as the most-performed improv form and iO signature piece. Charna Halpern, owner of the iO and Close's long-time collaborator, has cherished the rumor that Del Close's ashes and skull sit on an altar at the iO, and never tires of relating the mythology of his life and death (Butler 35-36, Halpern, Art 99-130). ${ }^{4}$ While is not part of my project to discuss how to judge Close's character, it helps to consider briefly the discursive function of his figure for improv's self-making discourse. Close was an important contributor to what we know as US improv, even "one of the most influential figures in

3 Byrnes is neither a much-noted critic nor a comedian, but his article sums up some arguments made against improv in general. Regardless of his intent or qualification to speak on the subject - his curtailed understanding of the "yes, and" principle is disproven in many other examples considered - he puts forward a view on improv that is real, whether or not it is "true." Also, aspects of his article resonate with arguments put forward in the discourse, like the cult or religion simile considered here. Moreover, reactions to the article from within the community - by professionals and non-professionals, most notably on Reddit and in the comment section of the article - speak to how insiders perceive themselves and how improv is perceived by non-improvisers.

4 Another account of his death is given in Kim H. Johnson’s “As Del Lay Dying” (2003). 
the history of American comedy," as Eric Spitznagel writes in "Follow the Fear," a balanced essay on the person and his mythologization. Close has attained a carefully-developed and maintained status as the most important one, the only one, the guru. He fabricated a thorough mysticist and anecdotal narrative about his own life, which he celebrated as a mixture of truth and things that sound like it. Spitznagel, when asked to write a profile of Close for a Chicago newspaper after Close's death, was confronted with many secondhand accounts from colleagues and friends, but "nobody seems to know with any certainty whether any of his stories are true." Spitznagel observes that "since his death in 1999, Close's stories have become a permanent fixture in improv mythology." The discourse is not short of publications invigorating this mythologization. Spitznagel summarizes:

There've been two films, including PBS's The Legend of Del Close (2000) and The Delmonic Interviews, a feature-length documentary that still screens on the national festival circuit, most recently at the Phoenix Improv Festival in April 2007. "Bring Me the Head of Del Close," a stage show that consisted solely of performers telling stories about Close, played to sold-out crowds at the Strawdog Theatre in Chicago during late 2004. Jeff Griggs wrote a memoir, Guru: My Days with Del Close, about his experiences working as Close's assistant and errand boy, and Kim Johnson - who, along with Close and Charna Halpern, cowrote the quintessential textbook on improvisation, Truth in Comedy - is reportedly working on a more comprehensive biography. Most famously, there's Wasteland, the short-lived DC comic book that Close cowrote and considered his autobiography.

While imagined (or remembered) as an outstanding and influential comic, as an eccentric guru of sorts who mixed theater and improvisation with drug use and celebrated the Gonzo lifestyle, Close was much a child of his time, rather than beyond it. Both improv and Close's role in it must be read in their historico-cultural context, as Seham does in her historiography of what she calls the second wave of improv:

New Age religions, televangelism and fundamentalist religious sects, and "self-religionist" or self-actualization movements [...] and Scientology emerged to fill the empty space of any unifying or collective belief system for many Americans in the 80s. (33)

Close claimed to have been friends with L. Ron Hubbard, to whom he had allegedly suggested that if he needed money, he should "just turn Scientology into a religion," only to state later that "Just because it didn't happen doesn't mean it isn't true” (Spitznagel). The language of religion and spirituality found a direct way into Close's improv practice and discourse. In the improv bible Truth in Comedy, the reader learns about a performance game or an exercise called "invocation," in which "students invoke a 'god"” (Close 108-09). What may sound 
like a metaphor, an image to give students to develop something from nothing, may at the time have been taken literally. Improv students may have thought they were in fact invoking demons, and Close may have believed himself to be "protecting" them against those demons (Halpern, Art 104). ${ }^{5}$ And after the suicide of his mentee James Belushi, Close sought help in spiritual leadership:

Rather than turn to counseling, Close found renewed inspiration in unlikely places. He immersed himself in the occult teachings of author Aleister Crowley and became the Warlock at a local Wiccan coven. Close was so enamored by his new spiritual beliefs that he began drawing on Wiccan rituals for his improv workshops at the Second City. (Spitznagel)

Through figures like Close and the stories associated with him, we learn about the structure and discursive mechanics of a community that creates and maintains this figure. There is something to be learned about a community in the figures around which they are built, in this case, a messianic leader and authoritarian gatekeeper of the "real" knowledge of universal truth, humanity, and humor. This also involves the exclusion of those unwilling or unable to get initiated (and accepted) into the cult, and, like other cults, manipulates through the language and ascription of talent (or lack thereof). If we can assume that some people have it, then we are quick to believe that those uninterested in such a cultish community do not. The idea of talent in combination with authoritarian assessment is, in fact, cultish. If Del Close had been a Black woman, improv would not be such a white space now - but then it might not even exist, because the discursive space of improv could never provide a Black woman figure with the unquestioned respect for the messianic leadership ascribed to Close. Close has been discursively chosen, collectively appointed, perhaps even retrospectively created as a guru - regardless of who he actually was or

5 To the contemporary reader, this might be far-fetched speculation. But we should keep in mind that it was the time of New Age fetishes, which are regularly raced, as we see in the following quotation. The idea of improvisers actually invoking demons is part of the mythologizing discourse as reified by Halpern, who recalls her first encounter with Del Close:

Art the performance, he gathered his students in a circle and began to do something called "The Invocation." And, since it was Halloween, they decided to invoke demons. At the time, I was taking classes in meditation and had been taught to do something called "white lighting" yourself. It was a method of protecting yourself by imagining your body surround in white light [...] After the very creepy performance, I decided to go up to him and give him a piece of advice of my mind [...] I said to him, "You had a lot of nerve invoking demons without protecting the audience." He responded in a condescending manner, "I protected the building." "You can’t do that," I responded. He stared me down and said, "Yes, I can." (103-04) 
what he actually did, about which I can make no reliable claims. But so much can be said: understood as a structural space, improv has little issue with such cultish guruism.

However, some parts of the community do react when the paradox becomes too obvious, as happened in a controversy about an annual improv marathon in New York at the UCB in 2017. The marathon was initially advertised with a poster that Seth Simons describes and interprets for Paste Magazine as follows:

Let's just mull over the image for a moment. So, that's Del Close right there with the big face and glasses. He appears to be embedded in the side of a mountain, Mount Rushmore-style. Or maybe he's lying against it, the rest of his gargantuan body out of frame. There's the Statue of Liberty atop his head, for some reason, and a neanderthal at the bottom, gazing quizzically upward for some other reason. Then we have everyone either ascending to the top or celebrating there, men and women, and some guy wearing salmon-colored shorts. And then there are the faceless masses approaching in the darkness. And then, to the side, two words: "The Wokening." What is The Wokening? Is it Del Close? Is it the Marathon? Is Close literally saying "The Wokening," and it's, like, a speech bubble, perhaps signified by what looks like a megaphone to his right? Has he just shouted "The Wokening" and everyone's streaming toward him so they don't miss The Wokening, which reads sort of like it may be a reference to "The Happening," or maybe it's just its own thing and not a reference at all? Unclear. ${ }^{6}$

To present Close in this way as the leader of an improv community (local, global, transreal) caused a backlash mostly among non-white improvisers on Twitter and Facebook. This punctum in the discourse sheds light on the space in which my project is located. Whatever truths can be said about Close, as an improv community, we should be wary of the gurus we choose and what they say about us. A culture that indulges in such a personality cult, including the modalities and contents that come with this specific figure, will necessarily be uninteresting or off-putting for people looking at it from the outside - or example, in Byrnes's general derision of improv, or in this observation from Kimberly Michelle Vaughn, ${ }^{7}$ who simply does not play along with the celebration of Close:

6 The poster is reproduced in the article by Simons.

7 Kimberly Michelle Vaughn graduated from Columbia College of Chicago with her BA in Theatre. An alumnus of The Second City Touring Company ("Red Co"), she opened "She the People: Girlfriends' Guide to Sisters Doing It For Themselves," Second City's first show created and performed by women. She also performed in Second City's "\#DATEME," "Legendary Laughs," and their 107th Mainstage Revue "Algorithm Nation or The Static Quo." Her TV credentials include The Chi (Showtime) and Written Off (Amazon). More information is available on her website. Our conversation took place in March 2015 in Chicago. Vaughn authorized the material used in this project via email on 8 October 2019. 
Everyone in that community hails Del Close. They love him. That man did not believe that black people can improvise. He did not think women can improvise. I don't give a fuck about him. (personal conversation)

UCB's official reply to the backlash was largely judged appropriate. Still, the undercurrent was defensive: "He was a provocateur, anti-establishmentarian and someone that truly cared about the misfits and weirdos," and, "While Del's contributions cannot be overrated what we are attempting to highlight are other voices empowered by this art form" (Simons). In these comments, we can see part of the problem. This issue does not lie in the fact that his contribution is somehow underappreciated. Rather, it lies with the fact that its racial axioms, its violence, and its anti-Blackness are unrecognized. While these features sometimes run along with discussions of Close as a guru figure, they are not read as their logical consequence. Toni Morrison asks us to be "mindful of the places where imagination sabotages itself, locks its own gates, pollutes its vision" (xi). This is also true for understanding improv and its original leadership by Close.

So is the idea of a cult helpful for this project? Is there more to it than the recognition that improv provides for its community and philosophy (Noble), or that "most popular improv advice sounds like spiritual challenges" (Hines)? First of all, understanding the discursive role of improv's contemporary practices of self-description, specifically the iO, is crucial. Second, the idea of an exclusive

8 Also compare the reaction to Byrnes's article by improviser Nelson Velazquez, who, in a blog post, agrees that

Improv IS a Cult (Sort Of). There's no shame in saying this. [...] Many people love the feeling improv brings of personal freedom to act like school children or finally finding like-minded, passionate individuals that love to do some things on stage or maybe just having a break from their mundane life for a few hours a week as an escape gets them on the hook. Those feelings and interactions can be addictive. You want to feel like that all of the time so continue to do improv classes, attend shows, hang out with all kinds of people, and do your own shows. That's called community and every cult's got one.

Velazquez does not accept, however, the notion of spiritual leadership for the entirety of the improv world:

The article goes wrong in not realizing that many of us don't "center ourselves around a messianic leader." There are many people across the world that are very much admired for their ability to use improv to make us laugh, cry, get angry, or feel uncomfortable on a consistent basis. Like any artform, we have our "heroes" for sure but in improv our heroes encourage us to find our own identities as actors and avoid being like them. This is completely contradictory to a true cult where leadership wants you to conform to what they preach irrespective of what you want to do with their teaching and will take actively take steps to shut down any form of dissent that may threaten their position. Improvisers look to inspire their own work from the greats out there. This is where the cult analogy breaks down a bit. 
cult with an uncritically accepted belief system applies as well. However, in this context, this belief system is partly bound up with but not restricted to the cult around a person (guru) or church (school), but needs to be understood in a deeper and wider context. The belief system is not the Harold as a gateway to ultimate truth. It is not Del Close, Second City, or the iO. The cult is called humanism, and its belief system is whiteness.

\subsection{Talking race}

\section{Black punctums}

In a culture that claims universal truths and humanity, Black absence - as well as its symbolic hypervisibility in the last couple of years - has been one of the most relevant, telling, and silenced talking points in improv discourse. If universal truths, human relatability, community-building, and even social healing are striven for through humor, and where satire is argued to provide marginalized voices the opportunity to speak, Black absence constitutes a problem. If egalitarian play and a general anyone-can-do-it-attitude are promoted, Black absence speaks to something for which improv discourse has no register, no grammar, no vocabulary. A community that understands itself mostly as liberal, egalitarian, welcoming, inclusive, can only do so by ignoring every voice that indicates a contradictory reality. Roger Bowen, an early producer of improvised theater, gives insightful commentary about why improv is such a white space. When asked "Why are there so few Blacks in improvisation?," his reply serves as a paradigmatic argument for understanding the anti-Black elitism of improvisers' self-conception as satirists:

I think that satiric improvisational theater is definitely a cosmopolitan phenomenon and the people who do it and its audience are cosmopolitan people who are sufficiently liberated from their ethnic backgrounds to identify with whatever is going on throughout the world. They know what a Chinese poem is like and what Italian food tastes like. But I don't think most black people are cosmopolitan. I think they're more ethnic in their orientation, so when they're black actors, they want to do black theater. (Bowen qtd. in Sweet 40)

The concept of cosmopolitanism can only function here semantically in its difference from what Bowen makes out as an "ethnic background" within a racialized binary of possible conditions. The white cosmopolitan state of being is synonymous with the political subject of the modern West, which Sylvia Wynter identifies as "Man1" and will be considered in more detail in the next chapter. This 
state involves the imagined transition from a natural to a civilized state of being by way of "sufficient" liberation from an "ethnic" state of being. This liberation, according to Bowen, finds expression in a refined taste and perfected human development. It is characterized by universality as such, which involves spatiotemporal and cultural omnivoracity. "Ethnicity" or "Blackness," on the other hand, is the background from which the modern, cosmopolitan man is distinguished. Bowen argues that improv is too intellectual for those racialized as Black. In this way, Black-racialized skin forecloses the possibility of a Black improviser by signifying their incapacity to liberate themselves. Bowen adds:

You see, ethnic art tends to emphasize, enhance, and reinforce certain states of values, to say, "Our group is a good group." But when you get out of that and you identify with a larger intellectual environment, you say, "Well, gee, that was pretty narrow stuff." You get a concept of the brotherhood of man and how much alike people are rather than how different they are. You become de-ethnicized and you become a citizen of the world. [...] Blacks aren't at that point. The ethnic experience is very enjoyable, but it excludes the outer world. It's always "Us against them." In some ways it makes it easier for a person to get along because he doesn't have to fight every single battle. Now, a cosmopolitan has to fight every single battle there is because he can't say, "Me and my tribe say, 'Fuck you," because he has no tribe anymore. The cosmopolitan person also, by the way, is in a position of having to improvise a whole way of life, whereas in an ethnic society, much of it is handed down to you; it's received tradition. (Bowen qtd. in Sweet 41)

Here Bowen juggles ahistorical concepts, cultural descriptors, and social positions, positioning himself and others in whatever way he sees fit. His unpersuasive arguments and lofty semantics answer the perceived lack of Blackness posited in the question. Bowen's is a paradigmatic example of how the repertoire of white defensive arguments can be put to use to minimize or mask the uncomfortable truth of improv's obliterative aesthetics. Even though the original question focuses on an absence, an irritation, a punctum, a lack in improv, Bowen is capable of explaining - even legitimizing - this absence by relocating the lack within Blackness rather than in the white space of improv where it was originally observed.

Over the years this project has taken, Black absence from improv has erupted several times in the discourse. My starting point was a then-recent 2013 article in the Chicago Tribune, in which Meredith Rodriguez engages with "the lack of diversity" on Saturday Night Live. Rodriguez traces the absence of Black cast members back to the improv scene of Chicago - and its racialized configurations - as the major breeding ground for future comedians. She observes that “those leading Chicago's improv and comedy scene say that although women and minorities have been breaking down barriers in the last several years, finding enough minorities for [Chicago's Improv] main stages remains a challenge." 
She is seconded by Andrew Alexander, then CEO of Second City, who agrees that "[w]e always have to do more," adding that "[t]he bench is fairly thin" and "[i]t's not like we have a lot to draw on." Alexander seems to be doing the best he can, investing "millions of dollars in Second City's diversity program” over the last two decades, financing "workshops at inner-city schools, casts that feature minority talent and scholarships at the Second City training center." According to the article, Second City's Outreach and Diversity coordinator Dionna GriffinIrons had an annual budget of $\$ 200,000$ at her disposal in 2013. Charna Halpern, the head of $\mathrm{iO}$, faced similar problems despite advocating a race-neutral perspective: "Halpern does not keep quotas or look specifically for minority actors, she said, saying that she simply looks for the 'best players." Halpern continues: "I have some coming up for further auditions. [...] They just need to get wet behind the ears." In this article, Black absence is presented as something to be solved and measures have been taken to do so, with slow effects. The same day Rodriguez's article was published, The New York Times featured an article titled “'S.N.L.' to Add Black Female Performer” by Bill Carter. The article reiterates the allegedly race-neutral argument by stating that executive producer Lorne Michaels is "purely driven by talent considerations." This alleged colorblindness is undermined by Michaels himself, who states that it is "100 percent good for the show to have an African-American woman." Carter points to Michaels's claim that this "is not merely because the show could use a woman capable of playing the first lady, Michelle Obama, in sketches," but reminds the reader that this is "important enough a consideration that all the candidates will be asked to try an impression of her Monday night." Notably, this decision was not arrived at without public and individual pressure:

\footnotetext{
"S.N.L." had been subjected to a barrage of criticism over the last several months over what seemed to be a glaring absence on the comedy show, which has had relatively few black female performers over its long history. The criticism was kicked off by comments from two of the show's black cast members, Jay Pharoah, who said the show needed to "follow up" on the promise to add a black woman, and Kenan Thompson, who announced he did not want to do any more impressions of black women in drag. (Carter)
}

With the introduction of UCB-trained Sasheer Zamata to the SNL cast in 2014 (she stayed until 2017), the debate was assuaged until September 2015 when a long and detailed blog entry by Oliver Chinyere re-opened it. In "Why I'm Quitting UCB, And Its Problem With Diversity," Chinyere states:

UCB does not care about black people or minorities. It does, has done and will continue to do the bare minimum when it comes to maintaining diversity not unlike the entertainment industry at-large. As nine openings on house teams quietly came and went, not one POC 
[Person of Color] was added, despite the fact that in the past year, two POC have stepped down. We are technically less diverse from a racial standpoint.

Chinyere's blog entry was widely received, and such temporary interventions on Facebook or in online newspapers and magazines function as powerful punctums within and against the white studia of improv. Keisha Zollar, former diversity coordinator at UCB, wrote a much-discussed post on Facebook in response to Chinyere, and a 92-comment Reddit thread continued the conversation ("r/Improv"). McDonald takes up the matter in an article for The Washington Post titled "Diversity problems persist for Upright Citizens Brigade comedy troupe, students say." She interviews Chinyere:

This isn't the first time these issues have bubbled up in the comedy troupe. Chinyere told The Post that a group of students met with the UCB "powers that be" in January 2014 and offered suggestions for how to improve the experiences of students of color. "Nothing was addressed on that list," she said.

Chinyere is not the only one to address the issue online. Other examples include the blog Miss Adventures of Milly (mirrytamalez, "My two cents about the lack of diversity in upper levels of UCB classes"), an interview with Peter Kim who also chose to drop out of UCB (“Comedian Talks Quitting 'Dream Job' At Second City Due To Racist Audiences”), the follow-up to Kim's article by improviser Simon Tran ("Resisting Racism on the Improv Stage"), Patrick Rowland's "What to expect if you're a Black Improvisor," or Keisha Zollar's appearance on the Acting Income podcast hosted by Ben Hauck, in which she discusses unconscious bias poignantly and in rich detail.

There are also rare instances of white engagement with Black absence, such as the episode "Inside the Master Class: Black Guy Auditions" in a UCB Comedy Youtube series about diversity. Rarely do these go beyond semi-ironic white helplessness in articulating anything on matters of race, as in the similarly sarcastic 2012 Onion article "Everyone In Improv Troupe Balding." If there is a discussion on anti-Blackness - most commonly in the register of "diversity" - it is always grounded in the presence of a Black racialized performer and never the subject of a white-on-white conversation. This is not a silent position per se, but improv discourse in general is not only extremely slow to react; it also finds no way of understanding how its fundamental whiteness causes Black absence. It never looks into itself. Ignorance has traditionally been and remains its ultimate silencing strategy. Those who talk about it are almost always Black performers. ${ }^{9}$

9 While the above examples relate to UCB New York (except for Chicago improviser Patrick 
In 2015 I conducted several interviews with improvisers, and the response to my call for interviews affirmed this; none of the improvisers to whom I was directed or who responded to my wide-reaching call were white. While I am happy that improv stars TJ \& Dave (TJ Jagodowski and David Pasquesi) were willing to talk to me, that contact was based on a personal encounter. It was always automatically understood that a) I wanted to talk only to Black people, or b) it is a Black people's problem of no concern for white people. This lack of white interest on questions of racialization comes as no surprise to the Black-racialized interviewees who were willing to talk to me. All Black improvisers addressed structural racism and told personal anecdotes that revealed improv's racism to be as incredibly present and powerful as the ignorance it encounters in white improv culture at large. Joel Boyd describes this phenomenon with an impressive effort at empathy:

A lot of issues where race comes up in comedy or improv in Chicago, there is a very small tight-knit group of people who discuss those things between each other. I only talk about it because most of my friends do that. I don't know that a regular Joe Shmoe improviser who moved here from Charlotte or somewhere, who just came here to do improv, I don't know, what that person is thinking about.

In general, a lot of white people who wouldn't necessarily encounter these kinds of problems on a day to day basis - How would they seek it out? It's a problem they don't have. It's a problem that they don't understand. And that they don't need to understand because they live in that other world where it doesn't exist for them, so why would they? I mean, I am sure that that's what's going through their head. It's not even racist. It's just- Their lives are fine. If this issue was solved or wasn't solved - their lives would be the same. I understand why white people don't talk about it on a daily basis. It's untalkable. I do it on stage because I think it's very important for us to not be silent about this kind of stuff. It's not gonna get solved if you don't say anything. There are a lot of deep social issues today that probably won't get solved just because people aren't willing to talk about it. But at least improv can bring those things to the light so that people at least talk about how they felt about this one scene after the show.

Whenever I have conversations about stuff like this, I always feel like it has to be at the right time and place. It almost feels like you have to know what you're getting into. The people getting into that conversation have to know that they are coming into the room to have that conversation. The only times I have talked about this have been forums and discussions among black student union. Even our outreach and diversity at Second City have sponsored two or three events with pizza and stuff, and they bring people to talk about stuff like this. But other than that, in our society, people just aren't ready to talk about it. It's such a "hush-hush put it under the table." I think if that was an aspect of im-

Rowland), the issue is as Western and global as anti-Blackness itself. From London, Tai Campbell writes: "Black people don't exist in improv. Well, there are about five of us. In a world where talking unicorns are real and time travel is possible, we don't exist. We don't exist as characters (even offstage), as performers, teachers, or as prominent voices in the improv world.” 
prov classes, it would help. At least a section, like a day: "This week we're gonna focus on this.” I definitely think you couldn't do it as a weekly thing. Nobody would come back. But I definitely think that it's a road, that if we don't take it, it's going to get worse. (personal conversation)

Patrick Rowland points out the paradox of a "welcoming" community unable to or uninterested in realizing improv's assumed potential to "be for everyone," zooming in on the need for pushing the debate:

This community is crazy welcoming. They welcome you, but it's weird that it's that thing where it's so few of us. And I'm not only talking about black people. I'm talking about Latinos; I'm talking about Asians, they're even a smaller percentage than black people. Any team at Annoyance or anywhere and you'll see it's just a lot of white guys, maybe one or two women, and maybe somebody of color. I think the reason that me and Nnamdi [Ngwe] are all more willing to talk about this is we're trying to get that word out, trying to get more of us to take classes, so everyone knows it's not just for white people. Not just for the tall, lanky white guy with glasses. It's for everybody. And I think we all need to work harder just spreading that message. I think because people are so used to it, they forget that there's this whole other margin of the world that is missing out on it because you're not talking about it more. (personal conversation)

Kimberly Michelle Vaughn is not surprised over the lack of interest from white improvisers:

I don't feel like that's on their mind. I don't think that's their goal or their mission. They won't say, "Let's get some real voices in here. Other voices than ours." I am not saying that their voices don't matter, but still: "Sit down, we've heard yours before. What the fuck are you complaining about?” I honestly don't know what we can do to change that. (personal conversation)

Dacey Arashiba ${ }^{10}$ wonders if white improvisers may simply feel that they have nothing to say about it - again making Black absence an issue for those absent rather than an impulse for white autocritique. He also considers the effect that an overwhelmingly white community performs with the lack of people who understand racism, and who are able and willing to call it out:

10 Dacey Arashiba writes and performs sketch comedy with the Asian American comedy ensemble Stir Friday Night! (see ensemble website), and sings in a punk rock choir called "The Blue Ribbon Glee Club.” He was a professional musician, and one of his compositions features in the movie D2: The Mighty Ducks 2. The conversation took place in March 2015 in Chicago together with Warren Phynix Johnson and Derek Schleelein. The material used in this project was authorized by Arashiba via Facebook Messenger on 7 October 2019. 
The white kids might think they don't have anything to add to the conversation. There is no canonical opinion about race in improv. I've seen plenty of things that devolved into stupid racism. Because there are no people of color in the crowd, nobody is paying attention to how stupid some things actually sound. Sometimes you have to call kids out about this: "It's a cheap laugh, but you gotta approach it differently. How do you play this smarter?" (personal conversation)

If it was structurally understood that the absence of Blackness means something for improv as a whole, a sensibility might emerge for the community, the cult, at large. But as a cult, improv has its teachings in place, and lacks the teachers who could address it adequately:

[Racism in scenes] is not talked about in class, really. Most teachers won't call it out. There's a thin line between stifling the student - 'cause they're paying for this class - but also you don't want that at the expense of your other students who are not comfortable. So it's a weird line for teachers to walk and I understand that. But if you don't have an advocate when you first start, if you don't have a teacher who has your back, someone who can tell you that it's not just you, I wouldn't believe that it gets better. It does get better. Some teachers will talk about it when it comes up organically, but it is not part of a curriculum. I wish it was. How to be a good teammate and how to not make your women castmates or castmates of color feel like props on stage. That should be something that's taught. And most of the time, when I tell people how I feel about what they do and what I find offensive, it's the first time they're hearing it. So a lot of people of color just ignore it, because it's hard to always have to be the person who says "Can't do this. Don't do this. That's wrong. That's mean. That's offensive.” You don't want to always be that person because you got a reputation. But if you don't, a lot of people won't know. But how would they? A lot of teachers don't teach or even only address it in class, which makes it not a fun learning environment. (Bullock, personal conversation)

\section{Racializing factors}

Those who do acknowledge the reality of Black absence regularly relate the racial question to other forms of discrimination and debates about the representation of "minorities." When speculating about the reasons for Black absence in improv, three explanatory fields come up repeatedly in the discourse: a lack of exposure, argued within the logic of representation; issues in infrastructure that center around geographic location and culture; and socioeconomic factors, including a culturally specific libidinal economy. First, every improviser I talked to identified a lack of representation and general awareness of improv in Black communities as one of the main reasons for Black absence: 
I think when theatrical improvisation started, it was a white person's game. Why that is, I don't know, but for a long time, there were no or very few minority performers that a young minority person could look to in order to emulate. I worked in the box office at Second City, and during my downtime, I would look at old cast pictures and can count on one hand the minority performers that were in those pictures for the first 30 or 40 years of the Chicago theater's existence. I don't know the Toronto or Detroit casts at all. And the same can be said for old pictures at ImprovOlympic. So, without seeing themselves represented in the histories of those theaters, I can see it not seeming like a place where they felt welcomed. It feels like improvisation was slower to arrive at its black stars than say, stand up or music or film, but I only know my corner of the improvisational world, and improvisation was slower to find its stars in general. It feels like only in the last twenty years that people have understood nationally what improv is and who its star pupils were, with the occasional exceptions of people like Nichols and May. (Jagodowski, email follow-up to personal conversation, 16 Oct. 2019)

I think the reason that the vast majority of improvisers are white is that the vast majority of people exposed to and interested in improvisation are white. Or rather have been. I also think that is changing. During the time I have been involved with improvisation, I have seen women better represented as each year passes and the same with other groups of people. I believe that as the pool of improvisers better represents different groups, improvisation becomes more available to potential new improvisers. Current improvisers are the ambassadors and recruiters for new improvisers. Some people need to see someone who looks more like themselves doing it in order to say, "Hey, they're like me. Maybe I can do it too." (Pasquesi, email follow-up to personal conversation, 20 Nov. 2019) ${ }^{11}$

\section{Black absence from white improv is understood as a kind of magical vicious cir- cle. To recognize the lack of representation is not to understand its reasons, and suggesting that Black absence is the cause of Black absence is circular logic. What other reasons are mentioned?}

11 David Pasquesi has been improvising since the early 1980s. He studied with Del Close for years and was on one of the original Harold teams at ImprovOlympic (now iO). Pasquesi wrote and performed four reviews at The Second City, where he received a Joseph Jefferson Award for Best Actor in a Review. He has played Steppenwolf and the Goodman theaters, and his many film and TV credits include VEEP, Strangers with Candy, Boss, Angels and Demons, and The Ice Harvest. Together with his partner TJ Jagodowski, Pasquesi has performed the fully improvised "TJ \& Dave" show on many stages throughout the USA, Canada, and Europe. The show has won numerous awards, such as the Del Close award two years in a row (2003 and 2004), Nightlife Award New York (2006 and 2007). Both performers have been celebrated as the "Chicago Improviser(s) of the Year" (2006) and the Chicago Reader named "TJ \& Dave" the "Best improvised Show" in 2008. For more, see his website, the "TJ \& Dave" website, and his book (with TJ Jagodowski and Pam Victor) Improvisation at the Speed of Life. The conversation took place in March 2015 in Chicago, together with TJ Jagodowski. The authorized material used in this project is drawn from a follow-up email exchange in October 2019. 
The argumentational foundation of Black absence from Chicago improv is the city's racial segregation, and the parallel distribution of financial resources. The three main Chicago improv theaters are all located in areas with a low to non-existent Black population. (See Alana Semuels's article in The Atlantic for a contemporary analysis of "Chicago's Awful Divide.”) The Second City and The Annoyance are in Lake View; iO is located in nearby Lincoln Park.

I am teaching several high schools in the Southside. I teach improv to high school students. And they weren't aware of Second City or SNL. Audiences in the Chicago area, especially downtown, in the Northside, because that's where most of the art is, and are all white. You barely get an occasion of a minority in there. It's great when you do, but you want more. We want to commercialize more and advertise more out there. There is no advertisement of the Second City in the Southside. Nothing. And iO might just as well be called the "white ensemble theater" because goddamn everyone is white. We just got to advertise more. (Vaughn, personal conversation)

When we conceive of improv spaces as geographical, we may also consider the actual physical spaces designed for improv training, performance, and socialization:

It's a question of pure infrastructure. You need stages; you need places to be, you need shows on a Friday night. If you're a poor black kid, you have no access to any of that shit. You might have access to a microphone to be funny in front of people, so you have stand up going for you. But you don't have theaters or anything like that. There is no financial structure as far as access to venues. You don't have that shit. Probably. I am speculating. (Schleelein, personal conversation) ${ }^{12}$

While this is a very white, rationalized point, I agree; if improv institutions and practitioners want to change their demographics, they will have to create this infrastructure.

The plan to open a Second City theater in Bronzeville in 2004 is a case in point demonstrating the challenges of infrastructure development. It also shows that spatial segregation is not only geographic. Allegedly "on a mission

12 Derek Schleelein regularly performs at the Annoyance and is part of the Bastards of the Underground, both in their improv and their radio work. He wrote and acted in The Thin Blue Line (finalist in Comedy Central Short Pilot Contest) and can be seen in web series such as My Bad Therapist (produced by \#Musenpet) and The Chip Ganzler Show. More film credits include the short films Liminal Vortices (SIGSALY Entertainment, assistant editor, script supervisor). Moving-In-Law (Studio Lumina Entertainment, production assistant) and Fast Looker (script supervisor). Our conversation took place in March 2015 in Chicago, together with Warren Phynix Johnson and Dacey Arashiba. Schleelein authorized the material used in this project via Facebook Messenger on 7 October 2019. 
to better reflect the cultural diversity of Chicago" (Currie), the Second City planned for a theater and training center in the Southside that would "house five training center classrooms, a 150-seat theater, approximately four offices, and a bar facility for service of the theater" (Katz). Dionna Griffin-Irons, who was and is the director of the outreach program for Second City, described Second City's goal in this endeavor to "incorporate different points of view into their comedy" (Katz). The idea emerged from the same grounds as the creation and development of diversity and outreach programs in Chicago's improv institutions, starting with the Second City: namely the inability of their all-white casts to speak meaningfully on the subject of the LA Riots of 2002.

"It was right around the time of the L.A. riots," Griffin explained. "Our actors were struggling to represent what happened in the riots. Then the idea kicked in that we have to have the African-Americans in order to represent what is going on. (qtd. in Katz)

However, Second City was not welcome in Bronzeville. In the anthology The New Chicago: A Social and Cultural Analysis (2006) Michael Bennett surveys criticism directed against the project, which was grounded in worries that "new investment in businesses and cultural enterprises may be intended not for their community but for the targets of an overheated real estate market." Moreover, the Second City's approach was perceived by some critics as a "racial and class-oriented encroachment into black cultural territory" (216).

The Chicago Reporter's insightful cover story on the Bronzeville project "New theater opening to mixed reviews" (Prince) - considers racialization in improv in a relatively nuanced way and includes a significant number of critical voices that address improv's whiteness. It is worth reading in full, but here are some excerpts:

Some Bronzeville residents and community leaders say that Second City is taking advantage of their work to rebuild Bronzeville, and benefiting from federal funding intended for struggling communities, not successful businesses. And some members of Chicago's black arts community are wary. They point to the low numbers of African Americans on Second City's staff and stages, and to the track record of Chicago improvisational comedy being, as one black actress put it, "a white thing." [...]

"It is a cultural slap in the face and a statement that we lack the capacity to develop that type of venue," said Harold Lucas, president of the Black Metropolis Convention and Tourism Council, a nonprofit Bronzeville-based organization providing entrepreneurial training to low-income residents. "I don't think that a European, North [Side], well-established comedy club should come into our community without broad-based support.” [...]

In March 2000, The Chicago Empowerment Zone and Enterprise Community Coordinating Council awarded Second City $\$ 850,118$ for the Bronzeville theater. The Empowerment Zone (EZ) is a federal program that seeks to revitalize distressed neighborhoods. 
However, some community members oppose Second City's EZ award and its move to Bronzeville. They call Second City a "foreign" institution. "We don't need Second City to save us economically or culturally," said Lucas of Black Metropolis. Second City is "walking into a ready-made market," he said. "Groups have been working for 20 years to preserve the authentic heritage of the community."

"This is a gross misuse of funds," added Nathan Thompson, a black author and activist. "Robert Townsend and Bernie Mac are the attractions that should be coming to Bronzeville, not Second City."

The white European mentality of conquer-to-save reverberates strongly here. Because of the ongoing racial dividing lines, whiteness is foreign to Bronzeville. The locals neither want nor need a white savior institution taking their federal money away from them. Everything about this sounds horrific, even though Second City announced some structural decisions in anticipation of such criticism:

\begin{abstract}
Leonard said that the Bronzeville theater [...] will be half-owned and fully managed by blacks. Its shows will feature integrated casts with a majority of the performers being black, said Dionna Griffin , the new theater's producer. She expects the new venue to draw racially mixed crowds. Half of the new theater's ownership structure will be comprised of nearly a dozen black producers, actors, directors and instructors who are alumni of Second City's training center, staff and stages, according to Second City officials. The other half will belong to Second City. (Prince)
\end{abstract}

However, for reasons difficult to adjudicate now, the "Black Second City" in Bronzeville "never materialized" (Lambert 200). Its cancellation speaks to the fact that a) questions of infrastructure can never be reduced to infrastructure alone, b) Second City did not do a particularly good job in communicating the project, and c) improv is viewed by Bronzeville activists as a business, an institutionalized entertainment rather than a politically idealized space for spontaneous egalitarian play. Such viewpoints are significant, as there is d) a political and individual affect in play that demands specific racial and racially cultural sensibility, which is difficult for an institution like Second City to generate or communicate.

Given the lack of infrastructure for improv, other problems logically ensue. One of those is the flow of information (or the lack thereof). People on the Southside of Chicago may simply not know about improv or encounter advertisements for shows or workshops. Perkins states that "When I went to college, I didn't even know what Second City was. My dorm went on a trip there and I was like, 'What is this thing that's been in my city in my entire life that I have never heard of?"' (personal conversation). For Patrick Rowland, it was the same: 
I grew up in the West side of Chicago, where it's all black community, and we never knew about improv. We know about stand-up comedy because of Eddie Murphy, Richard Prior, and all that, but when it comes to improv, people would always say Wayne Brady. That's all people would know about black people in improv. (personal conversation)

Information flow involves specific channels of communication and targeted (imagined) audiences. As Loreen Targos ${ }^{13}$ suggests, a special effort must be made to advertise for an audience other than those informed by default (given their social sphere or general interest). It requires other avenues and methods:

I went to go and see last year's Bob Curry fellowship thing. Me and my friends came to see it. It was less than five people there, so they canceled it. We thought that that was bullshit. What I think is that you need to do more outreach and marketing if you have a diversity show to get the same size audience. You need to push it harder and tailor it to minorities. Otherwise, they won't hear about it. If you do normal improv marketing, you will always only hit white people. (personal conversation) ${ }^{14}$

It would be misleading to identify these advertising barriers solely as geographical or due to a lack of awareness. Significantly, Vaughn considers the affective dimension that Black people may feel when wandering about in white spaces to see or to train in improv:

It's so weird that people in Iowa can know Second City, but not people from the Southside, in the same city as Second City! I don't know how to bring awareness to them. A lot of the times, the parents are afraid to let their children out on the Northside or downtown. They're afraid of what can happen to their child. It's unfortunate that these children don't receive the same exposure to the arts.

Space structures libidinal investments like fear. The way one moves through the city reflects racialized segregation and racialized libidinal economies. Wandering around a white space is walking in continual physical threat, and so it is actively avoided. It may be far-fetched to suggest that the improv sphere as such threatens to kill a racialized person, but the universe in which it exists certainly does.

13 Loreen Targos performs with Stir Friday Night!, a nonprofit theater company founded in 1995. SFN is one of the nation's premier Asian-American comedy troupes and has been cooperating with The Second City and iO (see further the Stir Friday Night! website). Targos also performs stand up around Chicago and is a member of "PREACH," an improvised spoken word movement. She is a graduate of the Second City and Annoyance Theater programs and is a current student at iO Chicago. The conversation took place in March 2015 in Chicago. Targos authorized the material used in this project via email on 13 October 2019.

14 During my stay in Chicago, I specifically sought out shows with Black improvisers. Two shows were canceled because I was the only one in the audience; both had Black performers. 
Black-racialized people may libidinally invest these white spaces with fear because they know that whiteness means violence. It may be an active, conscious, and sensible decision not to go there because such safe spaces are only safe for white people.

Other more pedestrian barriers exist as well, such as the distance from the Southside to the improv locations: getting to The Annoyance Theater, the iO, or The Second City from the Dan Ryan/ $95^{\text {th }}$ (Chicago's southernmost expressway) takes almost an hour, plus the time to get to and from the metro stations. However, the ultimate barrier is of course financial:

Schleelein: There is a very large barrier of entry as far as class is concerned. How many young black people are going to be like, "Yeah, I'm gonna take improv classes." You cannot afford that. There is a very distinct monetary barrier between the classes.

Arashiba: To take the entire syllabus in Second City is going to cost you two thousand bucks.

Schleelein: Two thousand, twenty-five hundred, something like that.

Arashiba: Four hundred to five hundred dollars per class.

Schleelein: Maybe it's worth it. It might be.

Arashiba: That's also where you'd meet everybody else doing improv.

Schleelein: But if you're a funny person in an underserved community who cannot drum up funds to take classes, you get on a stand-up stage. That's easy, that's right there. You're right there to do that shit.

Arashiba: The barrier is lower. And all the black people I know who have come into improv have also done stand up first. (personal conversation)

Not only do people have to pay to get into improv (pay to play), but there is also no certainty that it will pay off in the long run.

If you come from low-income families, a lot of times, you don't have the resources to make it in improv. Which is a lot of the reason why it's predominantly white. When I think about how much I paid on classes here before I got an internship - easily thousands and thousands of dollars. Not many people have that kind of money or that kind of time to make it all the way up here and take those kinds of classes, so it's a lot harder to get diverse talent. (Bullock)

Improv can thus be understood as a white economic luxury with little financial payoff, reinforcing one's perceived strength and sense of community and offering a privileged career path for those already privileged. It is a feel-good social luxury often impossible to attain in the white sphere for anybody racialized as Black. In other words, improv is a path to further achievement in the entertainment industry for those privileged by whiteness. 


\title{
Staging segregation
}

The factors identified above speak to the racialization of space as discussed by Charles Mills in The Racial Contract. He describes the normative racialization of space on three dimensions: "the macrolevel (entire countries and continents), the local level (city neighborhoods), and ultimately even the microlevel of the body (the contaminated and carnal halo of the non-white body)" (43-44). While the normative characteristics ascribed to these spaces have been discussed at length, it is worth pointing out that these dimensions are not only linked but, in political epistemology, create and reenact each other:

\begin{abstract}
The norming of space is partially done in terms of the racing of space, the depiction of space as dominated by individuals (whether persons or subpersons) of a certain race. At the same time, the norming of the individual is partially achieved by spacing it, that is, representing it as imprinted with the characteristics of a certain kind of space. So this is a mutually supporting characterization that, for subpersons, becomes a circular indictment: "You are what you are in part because you originate from a certain kind of space, and that space has those properties in part because it is inhabited by creatures like yourself." $(41-42)$
\end{abstract}

When we look at what is quickly framed as segregation, we must keep in mind that such segregation results from a racialization of space that is manifest in other dimensions, such as the individual body. We must not give in to the idea that Chicago, one of the most segregated cities in the US, has a problem that can be solved by establishing or improving an "improv infrastructure." Because this is so, Second City Bronzeville could not have happened; the psychic, political, and moral structure that gave rise to the project mirrors "European cognition," as Mills would say, which assumes that

in certain spaces real knowledge (knowledge of science, universals) is not possible. Significant cultural achievement, intellectual progress, is thus denied to those spaces, which are deemed (failing European intervention) to be permanently locked into a cognitive state of superstition and ignorance. (44)

Second City's attempt to build a theater in Bronzeville performed such a "European intervention" with very "European" moral, financial, political, and missionary intentions, and was consequently rejected by the people inhabiting that space. However, the characteristics of the racialized space - the impossibility of real, i.e. European, knowledge - are also applied to the individual racialized body. Vaughn considers the racialization of space within the improv community: 
We can start a program where it's like "all people of color," and we're gonna have a scholarship for them and put up a sign and have an intensive for them and showcase the work. But all you're doing is segregating them as well. So, you can't win in that. And then they get mad because essentially it is kind of affirmative action. Getting us scholarships so our voices can be heard, because obviously, those white improvisers are not trying to get us out there. They don't really believe in what we have to say. They think it's gonna be all chicken jokes and talk about things that don't matter to them. But we have voices. There are people here who have never been to the Southside and do not know that it's not that bad. You can get stabbed at the Northside. Wrigley is fucking crazy. Everyone is labeling the middle easterners as terrorists. It's the white men who are killing people. (Vaughn, personal conversation)

The concept of Black "voices" comes up frequently, and with it the observation that non-white voices are not deemed relevant for white improv comedy:

With Stir Friday Night!, we definitely had Asian people come more to shows. I do suppose that white people feel like “This isn’t speaking to me.” Same with other minorities. Black theater will attract mostly black audiences. White people do not feel like it applies to them. All of us [the Stir Friday Night ensemble] play in other groups as well. And in all those places, our stories aren't as celebrated or centralized like in ours. In our group, we can tell our stories, and there is a synergy. Within our group, we have similar stories, or even if we don't, we better understand the need for you to tell your story more than if you were in some white group. It's just different. (Targos, personal conversation)

Even within an improv team, then, the individual body is racialized in that it is intuitively restricted to characters assigned to racialized spaces that cannot hold real knowledge, for example by giving them ghetto names:

So often you would watch a show with an improviser of color, and you would find that person in an awkward situation, an awkward scene in which you're like "I wish they wouldn't -" Like you feel embarrassed for them. A lot of times, it's not malicious, but if you're not sensitive to it, you say things that are annoying to people of color onstage. Like when you give them "ghetto names" subconsciously. It's always rewarding to me to see people of color in an awkward situation with a racist cast member - and how they can flip it and turn it into a beautiful scene. (Bullock, personal conversation)

I came into a scene, and I did a British accent. And the first thing my scene partner says: “There are no black people in London!” Which a) there are tons of, and b) why would you say that? Every time I come out in a scene, they automatically either label me as "Tyrone" or another "black person name." Or they would unmake me: "This guy will be the black guy.” They probably haven't dealt with a lot of people of color, so all they know is what they see on the news, what they see on TV, and that's their only way to filter what they're gonna say in the scene. And it's sad that that still happens. (Rowland, personal conversation) 
Consider the verb "unmake," which Rowland uses to describe the dynamics of such on-stage racialized labeling. This speaks to the way in which he is being confronted not with "discrimination" or a "stereotype," but ultimately with the repeal of his ability to play from "the top of his intelligence." white improvisers will, consciously or subconsciously, assume his mind can never harbor the real knowledge of white cognizers. Black-racialized improvisers are assumed incapable of telling meaningful stories, or even universal ones, but are thought to be bound to meanings of Blackness:

When the groups or shows aren't segregated, it becomes such an eggshell type of situation. With sketch, you have a little bit more control, but with improv, everyone is walking on eggshells. There will be scenes where just because one person in the scene is black, it changes the tone of the entire scene. I definitely know there are scenes that I have done, in which I got a laugh - or not a laugh - because I was black. I remember a scene in a freeze tag jam. I tagged out somebody who was on the ground, and I was on my knees. The first line from the other two people, who were my friends, they didn't mean to do this, but they said: "Oh, he's ours now.” And I thought I was being an animal. I wasn't even thinking a racist thing; I was being an animal that they found. And then immediately, the crowd goes "Ooooooooooh." And then we realized what they saw. They thought it was a slave scene. It just comes up in weird situations like that. (Boyd, personal conversation.)

Unlike Boyd, when asked whether race is always there once a Black improviser enters a scene with only white people, Johnson answers in the negative.

Schleelein: Warren, you say no?

Johnson: If a motherfucker makes you a slave in a scene. What you do as a slave in the scene is to make yourself a real human being. "Gerald, I told you to take that trash out yesterday." "Sir, I am going to take that trash out. But I am just so conflicted by how your wife can smoke a cigarette - and she's pregnant."

Arashiba: Don't make slavery the thing. The thing is still the relationship between the two people.

Johnson: Exactly.

Schleelein: That's how you get through it and expose how stupid it is, too. I don't have any way to relate to that premise except for the fact for the idea that you want to destroy that idea as soon as it happens. And I do think that's true: If you have a white person and a black person on stage, immediately it's gonna be some consideration of race - on any level. You're gonna think about it when those two people get up there. They can be married and

15 This is a common phrase in improv teaching attributed to Del Close. In a blog entry, longtime performer and instructor Jimmy Carrane states that for him, it means to make a "choice that comes from honesty, that reflects life." I am making this point here because the notions of honesty and life are common tropes in improv poetics. However, performing truth and honesty is a hard task for the improviser who is put into characters with their (always already putative) humanity unmade. 
immediately smash all the preconceptions you might have about black people, especially. But I think it's undeniable that when you see it, that it's there. I really would love to see a scene where that is not even acknowledged, but everybody always does it.

Johnson: Not always, that's not my thing.

Schleelein: I'm not saying you personally.

Johnson: Every scene I go in, I am a white guy. Every scene I step into, I am a white guy. Schleelein: Unless someone tells you you're a black guy, you are white.

Johnson: My usual thing is a white guy. But yeah, unless I'm defined -

Schleelein: I love it when the shit goes the other way. We did an improv show where it's just you, me, and somebody else, and you were like, "Yeah, we're all here, just a bunch of white guys."

Johnson: I am always the white guy in my scenes unless I am a) defined by somebody else, or I define it as myself. Always assume I'm a white guy, always. In all my scenes, I am always white because it's a neutral guy.

Mostly, when Black-racialized improvisers share anecdotes and perspectives on the subject, they make the point that the racial behavior of their white scene partners is "not malicious" (Bullock, personal conversation). However, these questions are not moral, because the Racial Contract creates such morality in the first place (per Mills). We need to remain in the sphere of structural analysis. It would not be helpful to consider what is or is not allowed on stage - by whom, for whom, on what grounds? - or who is or is not racist. Let us keep in mind that I am addressing a fundamental anti-Blackness from which nobody can escape, least of all white improvisers.

We must understand that Blackness matters, means, and signifies on the stage, and that we can frame this in Mills's concepts of the multidimensional racialization of space that structures the world on the macro-, local, and micro-levels. Accordingly, dehumanizing ascriptions of Blackness onto all of these spatial dimensions follow the same rules and dynamics. That is why we must understand how integration and segregation are not mutually exclusive but reciprocally affirmative. When we speak about segregation in improv, we must understand it in these various dimensions, including segregation within improv, within specific institutions, within groups, and between scene partners. An all-Black house team can exist in segregation. A Black improviser in a group can still feel segregated, which they may or may not have the interest or ability to "turn into a superpower" (Boyd, personal conversation). The issue of racialized, segregated spaces persists even when Blackness is absent from the white geographical and intellectual space of improv, and when it is present, improv remains segregated from within. The failure to recognize the multidimensional racialization of spaces is why the politics, rhetorics, and practices of diversity in improv and elsewhere are doomed. 


\title{
Efforts at improvement
}

Second City's outreach programs, motivated by the LA Riots in 1992, were the first in the improv world. Other companies have followed. As of 2020, Second City has broad offerings that range from scholarships and festivals to the central Bob Curry fellowship, a "ten-week master program that offers up to 16 fellowships to qualifying actors and improvisers from diverse, multicultural backgrounds to train and study at The Second City." Co-funded by NBC, the Bob Curry fellowship is tuition-free and "awarded to exceptional talent selected by audition and adjudicated by Second City directors and producers," as presented on Second City's website ("Diversity"). Additionally, Second City offers up the decidedly diverse ensemble "Urban Twist," formerly known as "BrownCo":

It's basically an accelerated process of a lot of the work they have at Second City. It teaches you how to put together an archive show, how to write it. You get paid a $\$ 400$ stipend, and you meet maybe two or three times a week, work on material and then put together a show that producers get to see. That's a really nice opportunity because it's specifically for people of color or diverse talent, and you don't have to spend years and years and years which you may not have the time to invest loitering around at Second City. (Bullock, personal conversations)

However, more than two decades later, Patrick Rowland observes the same problem in the context of ongoing anti-Black police murder:

\begin{abstract}
We're representing people's lives. We're representing their reality. You can't do that if you don't have a diverse enough cast. So you can't speak on stuff that's happened in Ferguson. Stuff that happened to all these black teens getting shot. It's hard to do that from a white perspective. It's a lot easier to bring in people who have that voice, who've grown up in that neighborhood, who have something to say about that and can put their own spin and their own voice to it. (personal conversation)
\end{abstract}

Looking back on many decades of professional improvisation in Chicago, TJ Jagodowski states that racial discrimination in improv is less of an issue than gender discrimination. He also observes a change in the casting processes, politics, and sensibilities over the years:

I don't recall racial discrimination in my personal improvisational history. I do recall some quiet gender discrimination. When outside teams were put together or casts aligned, the presence of a female performer was often an afterthought or an add on because "we need to have a woman." Also, it was a very different time for the LGBTQ community when I started playing. It was the generation of “Don’t Ask, Don't Tell.” That basic tenet permeated most of American life, so there was inherent discrimination against gays being able to be out and be proud. It was something that wasn't talked about very much. I don't recall any discrimination that I've come across in workshops or on stage. Di- 
versity plays a role for certain now in casting. It would be unusual to assemble a cast of any size that is all white, all-male, or all straight. In many ways, because it limits the scope of ideas that can be presented with proper representation or with personal responsibility. (personal conversation)

Second City is not alone in its "diversity efforts." Other theaters like UCB and iO offer forums, meet-ups, panels, diversity jams, and make other efforts of outreach. (See their respective websites for more.) Rarely, however, do the advertisements of diversity and inclusion programs consider or formulate the lack that motivated them in the first place. The argument is rather a transumption of the "cultish" origins of improv. Consider the Second City's value statement:

The Second City believes that everyone, regardless of race, gender, or sexual orientation should experience the gift of improvisation and the many life skills it helps develop in a safe, supportive way and is actively working to champion diversity, equity, and inclusion at all levels of our institution and associated programming. Our goal is to open doors, create a bridge, and make this work accessible and inclusive. We firmly believe that unique experiences and points of view are at the core of the art form our artists create and reflective of the audiences, students, and clients we serve. ("Diversity")

While improv, here institutionalized as Second City, harbors the problem and has always done so, it nonetheless presents itself as the solution. Being so fundamentally white is slowly understood to be an ethical dilemma; this is a lack on the part of improv, not on the part of those absent, who are implicitly blamed for their absence or even ascribed a lack of "life skills" or "bridges." But bridges to where? As if that twist in logic wasn't problematic enough, the talk of diversity and inclusion throws together heterogeneous groups, which it subsequently creates as homogeneously diverse in performative praxis. The DiOversity Scholarship at iO is "offered to POC, LGBTQIA, and disabled individuals in order to complete the iO improv program." It is presented as "one of many ways that $\mathrm{iO}$ is trying to ensure that more marginalized voices and performers from communities underrepresented at our theater, and in society at large, have a chance to get on iO's stage and put great comedy out into the world" ("DiOversity"). POC and disabled individuals do not necessarily share anything except not being in the position to form their own world.

Of course, this register of diversity is not specific to improv, and I examine it further below. Let us look briefly at how the rhetorics and practices of diversity are perceived within the community. According to Chinyere, at UCB New York, the debate about and programs for diversity fail to provide a grammar for visible change (not to speak of that which is "untalkable," to use Boyd's term): 


\begin{abstract}
Nearly six years into my stay at UCB and it is very much unclear what the purpose of the Diversity program is at UCB. Is it to remain compliant? To give the illusion that they care about diversity? I have taken several workshops and 17 classes at UCB since 2011, a few of them were paid for by this scholarship. So it can definitely help finance your journey through UCB - but that's only if you choose to stick around, re-apply and get selected.

You see, a lot of people who accept these diversity scholarships do not in fact stay, so much so that the Diversity program had to incentivize students with a second free class if they took the first within six months or year. Why, you ask? Because a lot of POC show up the first week of class - don't see a lot of folks like them and drop out. For context, I was the only person of color in my first four classes at UCB.
\end{abstract}

Why doesn't it "work?" The rhetorics of diversity represent the only register applicable and the only political strategy available. This is not a moral question or a political critique but rather speaks to the inevitability of racialization in improv discourse and practice - including the fundamental shortcomings and even more problematic assumptions they entail. What we need to analyze lies far deeper than the intelligible arguments considered here, so far from the thinkable that language and any strategies to do something about it keep failing. According to Vaughn, the concept of diversity is not a solution, but part of the problem:

In Chicago, there is very big segregation going on. And in the improv community, it's still that way. Even though we sometimes say "Hey, we need diversity" or "Hey, we need a black person or an Asian person" or whatever. But there's so not a voice. If you have to say that we have diversity here, obviously you don't. If you need to put a sign up saying "Diversity YAY!”, you don't have diversity. And why does it have to be that way where it is so segregated, and you need a white man, or you need a white woman, but you don't need more than just one black person's voice. Each of us have different voices. Each minority does. You can't have one minority represent all; that's unfair when you have three or four white guys up there. (personal conversation)

Whereas Bullock thinks of the Bob Curry fellowships as "a really nice opportunity because it's specifically for people of color or diverse talent, and you don't have to spend years and years and years which you may not have the time to invest loitering around at Second City" (personal conversation), Boyd makes a strong point about its ambivalence, finding segregational diversity at once "a good thing" and "aggravating":

Everything is segregated. Sometimes it's a good thing. Most of the time, it's not. Just the fact that there is still "Gay Night" and "Black Night" at a lot of theaters. And I get it because sometimes you have to market shows like that in order to find that demographic of people who would be comfortable watching that type of comedy. But the fact that Second City does have a diversity and outreach section that's really thriving and finding a lot of good minority comedians in Chicago is good because it is an avenue that we probably wouldn't have had in the way that some improvisers come to move here. I definitely think that there are 
people who just don't know what steps to take to get them from A to B. I have a lot of friends who have day jobs, kids, they are trying to go to school, they would never even have heard of the opportunity to take classes at Second City in order to do improv. They wouldn't have known that was an option for life, to pursue that as a career or hobby. So definitely that sector of Second City is doing great work. That's great. But it's also aggravating. (Boyd, personal conversation)

In contrast, Loreen Targos recognizes what for others may be a structural problem, but values its pragmatic effect over its negative repercussions:

I do see how people say it segregates the community. But it's segregated anyway. Before these groups were there, it was even more segregated. At face value, it seems like "Oh, you're separating yourself!” but I think people have a right to talk about their experiences and be in a space where they feel safe to express a particular part of their identity. A lot of the time, the majority does not make improv a safe space. (Targos, personal conversation)

Whatever these heterogeneous positions on diversity, white discourse ultimately has the prerogative over how it is represented, understood, coded, and judged. Consider this anecdote from Targos:

There was a group that I was in, and we were surprisingly diverse, accidentally. We thought it would be funny to call ourselves "Affirmative Action" because we were so diverse. And our coach, who was white, was like, “No, you shouldn't do that. People are gonna think that you got picked for this because of affirmative action, and that has a negative connotation." For us, it didn't have a negative connotation. He thought that for our audience, which was mostly gonna be white, it'll have a negative connotation. So we thought of something else. Something generic. (personal conversation)

\section{Failing rhetorics of diversity}

This project is flawed in that it is bound to a grammar it seeks to critique. In looking at diversity policies - potential ways to get more minorities on stage or to reduce discrimination - I would be theorizing, presenting, and arguing in a register that doesn't uphold these concepts in the first place. In a conversation with Frank Wilderson, Jaye Austin Williams considers the limitations of diversity, which cannot address the anti-Black structure of Western modernity:

[I]t's not enough to focus on "diversity" or to talk about racial hatred and discrimination in their broader contexts. Rather, it's about how anti-blackness constitutes a structured antagonism that manifests overtly and insidiously, and in turn, impacts everything else - not least, the psychic and physical lives of black people all over the world. ("Staging” 2)

Diversity as rhetoric, politics, and practice is mobilized to assuage the ethical dilemma of the white subject. Wilderson writes in Red, White \& Black: 
At the beginning of the twenty-first century, the irreconcilable demands embodied in the "Savage" and the Slave are being smashed by the two stone-crushers of sheer force and liberal Humanist discourses such as "access to institutionality," "meritocracy," "multiculturalism," and “diversity." (30)

The concept of diversity comes from a place of default violent whiteness while presenting itself (and being imagined) as an alternative, as progress. It appeases mainly white liberals or progressives who would be threatened by the consequences of recognizing the anti-Black violence that makes up (their/our) white subjectivity - regardless of how empathetic they think themselves when it comes to a generalized discrimination. As Wilderson observes:

\begin{abstract}
A lot of fear rears its ugly head among our so-called "allies" when we move toward that something deeper you're talking about; something deeper than inequality and injustice, as you point out. I think of it as a fear Left-leaning artists have of what will happen if we stage a black encounter with violence. They don't want to witness our singular relation to structural violence - start in with that and they will burn you alive, as a witch at the altar of the universal. (Williams and Wilderson 28)
\end{abstract}

Liberal and progressive concepts like multiracialism or diversity rely on the belief in minorities and ethnicity, whose function Karen Fields and Barbara Fields describe as a feature of what they term "racecraft." They differentiate "racecraft" from racism and race: "the term race stands for the conception or the doctrine that nature produces humankind in distinct groups, each defined by inborn traits that its members share and that differentiate them from the members of other distinct groups of the same kind but of unequal rank." For Fields and Fields, racism denotes "the theory and the practice of applying a social, civic, or legal double standard based on ancestry." It does not speak to an "emotion or a state of mind, such as intolerance, bigotry, hatred, or malevolence" but is "an action and a rationale for action, or both at once." It takes "race" for granted, but the terms are not the same. Whereas "racism" describes "something an aggressor does," race is believed to refer to "something the target is." $(16-17)^{16}$

16 In the ensuing chapter, I will go a step further - denoting that "race" is also a concept that transumes "Blackness" to avoid confrontation with the anti-Black structure in which modern subjectivity is born. Talk about "race" again becomes secondary, because I am not at all interested in - or even suggest anything could be said about - "what a target is," and the notion of "unequal rank" will be left aside, because Blackness ultimately does not rank at all. Anti-Blackness, though raced like other "ethnicities," has a more fundamental function. Racism as an "action and a rationale for it" will not be part of the discussion, because the idea of a rationale will no longer be relevant. However, at this point in the argument, I firmly believe that the reader new to such a line of reasoning will find this transition helpful. Additionally, the concept 
What they call "racecraft" does "not refer to any groups or to ideas about group's traits" but denotes "a mental terrain and [...] pervasive belief.” It can be objectively observed and has "topographical features that Americans regularly navigate," originating not in nature but in "human action and imagination." Racecraft is not racism; it is "fingerprint evidence that racism has been on the scene" (18-19). Terms like ethnicity or minority function discursively as substitutes for race, and are complicit in veiling the racist dimensions of the discursive grammar that makes them semiotically and affectively intelligible in the first place. Like a thick gauze curtain, in their lack of precision and in their powerfully immediate affective understanding, these more malleable terms provide a way for white liberal progressives to talk about race without having to acknowledge its racial foundations.

Fields and Fields point out the logical absurdities that follow from muddling the individualized and the quantitative dimensions contained in the concept of "minorities," which veils structural racism qua its function in and as racecraft:

"Minority" ranks alongside "the color of their skin" as a verbal prop for the mental trick
that turns racism into race. The word slips its literal meaning as well as its core definition,
which is quantitative. Vice President Spiro Agnew once demonstrated the trick uncon-
sciously. Responding to a question about American policy toward the white supremacist
regime in what was then Rhodesia, he said it was no business of the United States how
other countries dealt with their "minorities," by which he meant the country's black major-
ity. The quantitative meaning slips again in the paradoxical formula "majority minority,"
referring to the projected numerical predominance of non-white persons in the United
States in the not-so-distant future. If the logic were harmless, it would be hilarious. (28)

The flawed notions of minorities or ethnicity are nonetheless part of the foundation that creates the progressive concept of diversity in the first place. They are complicit in the maintenance of the racial system that brings them about and by definition can never work against it. They cannot be mobilized to alleviate Black suffering, because liberal thought, as it perceives itself as progressive, can never work toward its own ruination. In structural terms, diversity as a concept, a practice, and a political prerogative is an essential part of racecraft and functions to make racism, and anti-Blackness specifically, invisible to those who believe in it. The register of diversity involves a relationality between ethnicities and cannot provide a grammar for the kind of change it explicitly claims to foster. If (left) liberal progressive discourse could see the world without ignoring the anti-

(and modality) of the idea of "racecraft" as a mental terrain is helpful. I think this helps many readers to follow through to understand how "diversity" as a plurality of ethnic (or other) identities is in itself a racial concept, and, as such, useless to attack racism. 
Black violence that structures it, it would have to annihilate itself. As a concept and a term, diversity says as much by involving the anti-Black vector, pointing away from a default position inhabited by those not-diverse and throwing together the least-connected positions and non-positions provided by social life and death. When the iO offers scholarships to "POC, LGBTQIA, and disabled individuals," it is not doing much against racism in and Black absence from improv. Rather, it contributes to it by maintaining a social stability that is a "state of emergency" for Black-racialized people (Wilderson, Red 7).

\section{Improv and the politics of hope}

In his essay "Black Nihilism and the Politics of Hope" (2015), Calvin Warren argues that "[e]very emancipatory strategy that attempted to rescue blackness from anti-blackness inevitably reconstituted and reconfigured the anti-blackness it tried to eliminate." The rhetorics of diversity are located in the larger discursive vector he terms the "politics of hope" (239). Hope exists only for those who are understood to participate in the Political - a sphere which is by definition foreclosed to those racialized as Black:

The logic of the Political - linear temporality, biopolitical futurity, perfection, betterment, and redress - sustains black suffering. Progress and perfection are worked through the pained black body and any recourse to the Political and its discourse of hope will ultimately reproduce the very metaphysical structures of violence that pulverize black being. (218)

Such a frame helps to articulate the philosophical axioms activated here, showing that diversity politics are not in fact as paradoxical as they might appear because Warren enables us to theorize a "hope" that "pulverizes black being." To begin with, we must differentiate with Warren "between 'hope' (the spiritual concept) and the 'politics of hope' (political hope)" (218); while the former may "always escape confinement within scientific discourse" by convention and through discursive compulsion, it still attains "intelligibility and efficacy within and through the Political." With Grant Farred, Warren argues that "political participation is motivated by self-interested expectancy; this political calculus assumes that political participation, particularly voting is an investment with an assurance of a return or political dividend" (219). Such a return or dividend becomes a (Lacanian) "impossible object” for Black non-citizens (221), which makes Black political participation irrational "given the historicity of voting as an ineffective practice in gaining tangible 'objects' for achieving redress, equality, and political subjectivity" (220): 
This idea of achieving the impossible allows one to disregard the historicity of anti-blackness and its continued legacy and conceive of political engagement as bringing one incrementally closer to that which does not exist - one's impossible object. (221)

Warren suggests that recognizing this impossibility within the field, grammar, and engagement of the Political is hidden behind the logic of problem and solution that structures it. For every problem, the Political offers up a solution. When we look at the Politics of improv, for example, it is assumed that more exposure and representation, woke teachers, more diversity, or simply better infrastructure would solve its problem of anti-Blackness (as manifest as Black absence, segregation, or discrimination). It is rare that anybody would say "This cannot be solved."

Warren's concepts of Black nihilism and political hope theorize just that impossibility. They provide a clear view of the fact that a system is not capable of (or interested in) "solving a problem" that is constitutive of that very system. Political hope serves to veil that incapacity by continually projecting the solution into the future. Warren argues that the "idea of linear proximity - we can call this 'progress,' 'betterment,' or 'more perfect'” is the axiological ground for what he terms the "“trick' of time:"

Because the temporality of hope is a time "not-yet-realized," a future tense unmoored from present-tense justifications and pragmatist evidence, the politics of hope cleverly shields its 'solutions' from critiques of impossibility or repetition. (222)

This is the ground for every "good" action that intends to combat the problem, because taking action is related to problem-solving, as inaction will not change anything. However, the solution is dialectically dependent on the problem: "The politics of hope, then, depends on the incessant (re)production and proliferation of problems to justify its existence. Solutions cannot really exist within the politics of hope, just the illusion of a different order in a future tense" (223). Further:

To "do something" means that this doing must translate into recognizable political activity; "something" is a stand-in for "politics" - one must "do politics" to address any problem. A refusal to "do politics" is equivalent to "doing nothing." [...] To refuse to "do politics" and to reject the fantastical object of politics is the only "hope" for blackness in an anti-black world. (223)

The improv problem under investigation here can be solved in the sense that the solving as praxis is a means without an end. The "doing the solving" is the solution in itself, because in doing, improv can claim to be doing something. The entire diversity project and its political engagement must be read in these 
terms. Such empty doing does, of course, solve the problem that white people have with Black absence. Structurally speaking, it does nothing if not "aggravate" (Boyd) the anti-Black structures that Black improvisers regularly experience in their various improv-specific manifestations. It does not matter whether all this doing actually leads to something. Speaking with Warren, the politics of hope are even more efficient if it does not. From Black non-positionalities not solving it, staying away from this doing, would be the only "'hope' for blackness" (223). With Warren, we cannot but acknowledge that "political hope is bound up with metaphysical violence, and this violence masquerades as a 'solution' to the problem of anti-blackness." We must understand the axioms and concepts of "temporal linearity, perfection, betterment, struggle, work, and utopian futurity" as "instruments of the Political that will never obviate black suffering or anti-black violence" but as tools that "only serve to reproduce the conditions that render existence unbearable for blacks." This problem cannot be solved in the realm of the Political. It cannot be solved without ending the world as we know it, as Wilderson frequently puts it. Asking "What can be done?" is an exacerbation. Warren posits "political apostasy as the spiritual practice of denouncing metaphysical violence, black suffering, and the idol of anti-blackness. The act of renouncing will not change the political structures or offer a political program; instead, it is the act of retrieving the spiritual concept of hope from the captivity of the Political" (243).

The discursive environment and climate of improv is passive aggressive towards such fundamental criticism. Based on notions of improvement, ignorant improvisers will always prefer to fashion themselves as woke rather than acknowledge that their wokeness cannot be trusted. Making such statements, however, always hints at improv comedy "becoming better" in itself, or even playing a role in instigating a debate aimed at the betterment of society:

It feels like over the past six years, people are becoming better about it. I don't know why that is. Maybe because people started shutting that stuff down. But it still shows up. Nobody wants to control what happens off stage. Or be the determiner of what is correct and what's not. But at the same time, people are starting to learn that they have limits. (Arashiba, personal conversation)

I feel like comedy is one of those things that allows people to talk about those risqué topics in a fun way. Or at least when there is a joke on top, it's easier to hear about racism, sexism, classism or homophobia, all that kind of stuff. (Boyd, personal conversation)

Patrick Rowland articulates that ambivalence in the language and grammar of negotiation and progress, but is not particularly optimistic because he understands its ultimate aim as Warren's "trick of time": 
I was really happy when I heard about your project because I think diversity in Improv is still barely existent. It's crazy. When I started taking classes, I didn't see any black people or any people of color on the stages, and there wasn't really anybody of color in my classes. It's kind of getting better; I can at least count on two hands black people on teams here, but it's still slow progress.

I think it's just exposing more people to us, to people of color, having more of us doing shows and teaching. Like right now, I think Nnamdi is the only one of color here at iO teaching. And hopefully, I'm gonna start teaching soon. I've gone through the program at Second City and at iO and some at Annoyance, and I have never had a teacher of color teach me. It's just like if you have people already like teaching, able to nip that stuff in the bud when people are learning improv. I think it would start making things better. In an ideal world... I don't know if it'll ever happen. Sadly. I don't think it'll happen. (Rowland, personal conversation)

Through this sketchy report of anti-Blackness in improv, I now arrive at a simple point. It is surely a long stretch to consider every Black-racialized person who does not do improv a Black nihilist in this sense. But it does help us white people to understand why the improv we cherish is so white. And it forbids us to seek explanations of Black absence in the spaces, meanings, and individuals that inhabit the sphere of Blackness, unless we appreciate it as an active and conscious choice, and the only rational one to be made: a kind of improv apostasy in advance (or in retrospect, as some examples above demonstrate).

\section{In improvisation itself?}

When presenting the thesis of this project, I have repeatedly come up against one question or defensive argument: "Yes, that may all be true. But do you really think improv is worse than other aspects of life in that regard?" Most white improvisers are annoyed that I have become a race traitor (in their eyes), and do everything they can to defend their improv against the positions I have articulated. Such defenses miss the point completely. I am not interested in the morality of improvisers, in the potential of improv as an art form, or in strategies for its improvement in the solution of the diversity paradox. I am not attacking anybody individually any more than I am attacking myself, and I made a living on improv for several years and still perform sometimes. In addition, I cannot be sure that all (or any) of the arguments I am making would resonate with the Black-racialized improvisers and performers of color to whom I have spoken. Yet it is not my aim to find one coherent theorization of improv, to level the plurality, to eradicate ambivalences that the anti-Black foundation of modernity generates for people living in the real world. When asked about improv's specificities in this regard, Loreen Targos rejects the idea of improv being somehow special, and 
David Pasquesi shares the common white belief that improv, or improv training, may even hold some kind of a remedy to better the world, ridding it of "prejudice:"

I don't think people in improv are necessarily more or less enlightened than the general population. I think, if they are ignorant, it's a lot easier for them to demonstrate that ignorance because they're on stage being an idiot. (Targos, personal conversation)

I am aware of discrimination... that there is discrimination everywhere. I feel that I personally do not discriminate based on things like race, gender, sexual identity, religious beliefs, nationality. But I can't be sure that I don't. However, I definitely discriminate based on lack of ability or talent. There definitely are prejudices in the world and in the world of improvisation. But one nice thing about our little world is that things like prejudice are antithetical to being a good improviser. Inclusion, acceptance, and embracing differences are helpful in improvisation. So I think the problem with discrimination in improvisation lies more in the administration and business hierarchy and not in improvisation itself. (Pasquesi, email follow-up to personal conversation, 20 Nov. 2019) ${ }^{17}$

In my opinion, the task of the scholar is to maintain their legitimacy by respecting any position that does not conform to their theory. Freedom of speech, so to speak, does not entail freedom from disagreement, and debates about race are rarely without disagreement.

I suggest that improv, imagined as an aesthetic modality and practice, may not be immoral per se as long as we conceive of it purely as that. Yet such a perception is insignificant because a) there is no such thing as a pure aesthetics that is never realized, and b) morality and ethics are concepts and beliefs located in the assumptive logic of the Racial Contract and thus wedded to the Political. Improv is realized where people perform it - on public stages, in classrooms, wherever. And if we talk about it, we must concern ourselves with what actually happens.

I am pretty sure everybody has a story of that where they brought a friend and then felt embarrassed by what was onstage. It happens so much. It happens to everyone. It's almost a common thing. (Bullock, personal conversation)

At a Second City show [...] the Nommo Gathering Black Writers Collective, the only ensemble of black writers to go through Second City's training program, watched white actors per-

17 A note on "talent": for Wilderson, meritocracies are "stone-crushers of sheer force and liberal Humanist discourses" (Red 30). In the discussion of anti-Blackness, the idea of talent is a powerful derailment that blames the absent in an essentialist way. Aaron Freeman, the first African American performer at Second City, always knew that the "definitive question in a scene wasn't my talent, but what was appropriate to my skin color. It was a distinction that was made. That hurt” (qtd. in Prince). 
form a parody of the drug culture, said Stephanie Shakur, the group's executive director. "One woman was holding up an infant, giving it a bottle. Another walked up, with the stereotypical black cadence, and said, “Girl, what's wrong wit' you?” The other woman pointed at the baby and said, "Girl, she pregnant!" said Shakur. The mostly white audience hollered with laughter, she said, but a dozen or so blacks from the Nommo Gathering sat in stunned silence. (Prince)

In an advanced study class, my teammates once made the choice for me that I was stealing from a store. All I did was walk into a scene, alarms sounded, and I was arrested. What does that say when the only person of color in a scene is immediately arrested? (Chinyere)

It's so weird talking about it because we see it all the time. And I always have to remember that not everybody watches improv the way I watch it. And I watch improv as a person of color - "land mine over here, land mine over there." You're tiptoeing. And the more you do it, the less authentic you are as an improviser. It’s stifling. (Bullock, personal conversation)

When I'm on stage with a white actor, their first idea is "What's up, homeboy?" or -“You're in jail, and I'm the police officer," or they call me "Malcolm X." They already typecast me as a black person. If I have my hair in an Afro, that makes it even worse. (Ronnel Taylor qtd. in Prince)

I was at Second City auditions for level 3. A friend of mine asked me, "What advice can you give me?” I was like, “First of all: be human! Don’t be crazy all the time. And then: What is special about you? Showcase you." And she was really nervous because she was the only person of color within that group. She was like: "I don't know how to showcase myself and not make myself feel isolated." And I was like, “Oh, that's a problem that we all have at some point. But the more you do it, the more you figure out that you can use all of you as a human on stage. You don't go on stage as a blank slate. You have all your experiences as a person. So if you come upon something, just respond like you respond in real life." (Perkins, personal conversation)

All these anecdotes point vaguely to a field of investigation covered by phenomena that cannot be solved by the establishment, by improving infrastructure, or by increasing exposure for Black performers. They hint at something more fundamental than prejudice, something that is not specific to improv but addresses our understanding and mobilization of Humanism.

Here are my answers as to why improv's specific modal, cultural, historical, and libidinal configurations can and should be analyzed in their specificities concerning anti-Blackness. First, improv discourse (and its self-description) is so heavily built on a politics of hope, and is such a left-liberal progressive idea - and has been from its beginnings - that there is a specific need to address the anti-Black violence that undergirds it. Improv can be understood as a prime project of the politics of hope. The notion of betterment through improv can be found on the microlevel of improving individual personalities with effects on their personal surroundings, because "improv forces you to listen [and] teaches empathy and emotional intelligence" (Naameh; see also Streu and Wilson). 
There are also larger projects like Improv for Humanity, which believes in applied improvisation "to address the vast array of challenges facing us - from refugee crises and climate change, to disaster preparedness and working with vulnerable populations" ("Who"). With such powerful hope in the discourse, a thick veil disguises the violence that is the modern foundation of structural anti-Blackness. Second, as considered above, improv has recently discovered active problemsolving in the politics of hope. The debates that surround it are gaining some sort of (temporary?) momentum, and we can expect that anti-Blackness will soon find ways to recast itself. Third, and most importantly, several fundamental axioms and dynamics that constitute (and define) improv's poetics affect the reenactment of white supremacist anti-Blackness. Improv lore (both practical and academic) holds that improv can overcome old forms of knowledge by referring to a spontaneous reality somehow generated via access to intuition, the practice of play, and the mobilization of humor. I suggest that all these fields provide a specific pathway, a powerful channel for intuitive anti-Blackness to be performed. The imagined naturalness of intuition, the cherished egalitarianism of play, and the libidinal relief assumed to come with humor make improv particularly anti-Black through its aesthetic specificities.

This working hypothesis has crystallized for my project: improv is a ground, a safe space, for anti-Blackness to be realized under the rhetorical veil of progress, freedom, democracy - all of which have themselves been enabled and catalyzed qua anti-Blackness. This differentiates improv from other forms of expression in its parasitic procedure of spontaneous reenactment. Improv is therefore a case worthy of particular consideration. While it is feasible to argue that the world is flawed and that improv's flaws are a direct consequence of that (if understood in its specific configuration of intuition, humor, and play), improv's discursive design creates a terrain for the individual and collective libidinal economy that structures white modernity. Intuition, play, and humor can (and should) all be theorized in their libidinal motivation in the specific ways that empower and propel them, that drive them. Intuition, play, and humor can be linked conceptually to the anti-Black affect of modernity in the language of psychoanalysis. Improv, relying as heavily as it does on the Human who plays and laughs, must be affected by a critical examination of the concept. 